\title{
Characterization of vaccine and field IBDV strains in Ukraine for proper vaccine selection for disease prevention
}

\author{
A. S. Pastyria, I. G. Budzanivska, V. P. Polischuk \\ ESC "Institute of Biology and Medicine", Taras Shevchenko National University of Kyiv \\ 64/13, Volodymyrska Str., Kyiv, Ukraine, 01601 \\ ann.pastyria@gmail.com
}

Infectious bursal disease virus (IBDV) causes a highly contagious disease in young chickens and is distributed worldwide. VP2 is the major viral antigen. The VP2 gene contains hypervariable region (VP2 HRV). Mutations in this region lead to emergence of antigenically different IBDV strains. Vaccination is used for IBDV prevention. The efficacy of vaccination depends on similarity of field and vaccine strains. Aim. To analyze nucleotide sequences of different vaccine and field strains of IBDV circulating in Ukrainian poultry farms. Methods. Eleven vaccine strains and 16 field isolates were used in this study. RNA was extracted using a magnetic separation method, reverse transcription was carried out and PCR was performed using specific primers to the VP2 gene. The obtained amplicons were sequenced. Phylogenetic and amino acid analysis was performed usning the MEGA 6 software. Results. Eleven vaccine strains formed five phylogenetic clusters. Cluster I represented strains GM97, $228 \mathrm{E}$ and $\mathrm{MB} / 20$. Cluster II contained mild vaccine strains LC-75 and D78. Intermediate strains Winterfield-2512 and Lukert formed cluster III. 'Hot' vaccine strains MB and MB/3 formed cluster IV. Cluster V was represented by strains MB/5 and V877. After addition of 16 Ukrainian field strains, the tree structure remained the same. Eight isolates clustered together with 'hot', five, with intermediate, and three, with mild vaccine strains. Amino acid analyses confirmed the antigenic similarity among vaccine and field strains of the same cluster. Conclusion. The obtained data can be used for the vaccine selection for IBD prevention in poultry farms in Ukraine.

Ke y w o r d s: IBDV, field strains, vaccine strains, vvIBDV, phylogenetic analysis.

\section{Introduction}

Infectious bursal disease virus (IBDV) is a member of the Birnaviridae family Avibirnavirus genus. It is a non-enveloped virus with two segments of double stranded RNA. The
IBDV genome is divided into segments $\mathrm{A}$ $(3.4 \mathrm{~kb})$ and $\mathrm{B}(2.8 \mathrm{~kb})$. The large segment A encodes 4 viral proteins, the two capsid proteins VP2 (48 kDa) and VP3 $(32-35 \mathrm{kDa})$, the viral protease VP4 $(24 \mathrm{kDa})$, and a nonstructural protein VP5 $(17-21 \mathrm{kDa})$, while the

(C) 2018 A. S. Pastyria et al.; Published by the Institute of Molecular Biology and Genetics, NAS of Ukraine on behalf of Biopolymers and Cell. This is an Open Access article distributed under the terms of the Creative Commons Attribution License (http://creativecommons.org/licenses/by/4.0/), which permits unrestricted reuse, distribution, and reproduction in any medium, provided the original work is properly cited 
smaller segment B encodes VP1 (90 kDa), an RNA-dependent RNA polymerase [1].

Virus replicates in immature IgM+ B-cells residing in the bursa of Fabricius of young chickens and causes an immunosuppressive infectious bursal disease (IBD) [2]. Primary viral antigen and structural protein is VP2. VP2 gene contains special hypervariable region (VP2 HRV). Mutations in this region lead to emergence of antigenically different IBDV strains [3]. The most effective way of IBD prevention is vaccination with the live attenuated vaccines. These vaccines are divided into three groups: "mild", "intermediate" and intermediate plus or "hot" according to a degree of their residual virulence [4]. Mild vaccines are safe for specific pathogen free (SPF) chickens but are not very effective in the presence of high levels of maternal antibodies or against very virulent strains of IBDV. Intermediate and 'hot' vaccines are much more effective but may induce moderate to severe lesions in the bursa of Fabricius [5]. Choosing the appropriate vaccine is critical for controlling IBD because of the antigenic divergence observed among the serotype 1 viruses. Point mutations and recombination events have contributed to the antigenic drift and antigenic variation among IBDV strains. In order to choose the most effective vaccine it is necessary to analyze what kind of field virus circulates in the farm. Vaccine strain should be genetically and antigenically close to the field virus $[5,6]$.

This study was aimed at comparing VP2 HRV of different vaccine strains and field isolates detected in Ukraine to find the most antigenically close vaccine strains for prevention IBD in each particular farm.

\section{Materials and Methods}

In this study 11 vaccine strains (including 3 Ukrainian) and 16 Ukrainian field isolates were used. IBDV vaccines Polimun IBD light (strain $\mathrm{MB} / 20$, BioTestLab, Ukraine), Polimun IBD (strain $\mathrm{MB} / 5$, BioTestLab, Ukraine), Polimun IBD+ (strain MB/3, BioTestLab, Ukraine), AviPro ${ }^{\circledR}$ PRECISE (strain LC-75, Lohmann Animal Health GmbH, Germany), HIPRAGUMBORO $^{\circledR}$ GM97 (strain GM97, Hipra, Spain) currently used in Ukraine, are not presented in GeneBank, that is] why they were taken from the manufactures for the analysis of the vaccine strains. Also, several sequences of vaccine strains were taken from GeneBank, such as: D78 (AJ586963), 228E (AF457204), Lukert (AY918948), V877 (AJ878882), MB (AY739669), Winterfield-2512 (DQ355819). Ukrainian strains were isolated from different regions as described in previous study [7].

RNA was extracted with the use of magnetic separation method following supplier's recommendations (MagVet ${ }^{\mathrm{TM}}$, LSI) from bursa tissues samples and vaccine samples. Reverse transcription was performed using a commercial test kit (Reverta-L, Amplisens). Obtained cDNA was used for nested PCR. PCR amplification of hypervariable region of VP2 gene was carried out with specific primers [7]. The oligonucleotide primers used in this work designated Bur1F (5'-TCACCGTCC TCAGCTTAC-3' nucleotide position 587-604) and Bur1R (5'-TCAGGATTTGGGATCAGC3' nucleotide position 1212-1229) designed to amplify the hypervariable region of VP2 gene amplicon size - 643 bp. To increase specificity and sensitivity of the reaction the second set of primers Bur2F (5'-CGCTATAGCGCT TGACCCAAAAA-3', nucleotide position 
651 - 673) and Bur2R (5'-CTCACCCCAGCG ACCGTAACGACG-3', nucleotide position 1179-1202) designed by Kataria et al [8] were used which allows the amplification of the inner region of the first amplicon obtained after the first round of the amplification using Bur $1 F$ and Bur1R primers. The resulting product had the length of $552 \mathrm{bp}$. [The] First round of amplification was carried out for 1 cycle at $95^{\circ} \mathrm{C}$ for $2 \mathrm{~min}, 36$ cycles at $95^{\circ} \mathrm{C}$ for $30 \mathrm{~s}, 52^{\circ} \mathrm{C}$ for $30 \mathrm{~s}, 72{ }^{\circ} \mathrm{C}$ for $30 \mathrm{~s}$, and 1 cycle at $72{ }^{\circ} \mathrm{C}$ for $2 \mathrm{~min}$. Amplicons obtained from the first reaction were diluted by 20 times and used for the second reaction. Thermal profile for the second reaction was similar except the primer annealing temperature, which was $63^{\circ} \mathrm{C}$. PCR products were visualized in 1,5 agarosegel. Amplicons were separated from reaction components using the Thermo Scientific GeneJET Gel Extraction Kit. Purified amplicons were sequenced using forward primer (Bur2F) by Institute of Molecular Biology and Genetics NAS, Ukraine (3130 Genetic Analyzer,
Applied Biosystems, USA). Sequences were analyzed using Mega 6 software [9]. Nucleotide alignment was performed using ClustalW instrument. Phylogenetic analysis was performed using neighbor-joining method [10].

\section{Results and Discussion}

426 nucleotide fragments of [the] VP2 gene of IBDV strains were obtained and used for phylogenetic analysis. 11 vaccine strains formed 5 phylogenetic clusters. Cluster I represented strains GM97, 228E and MB/20. Mean nucleotide identity was $99.7 \%$. Cluster II contained mild vaccine strains LC-75 and D78 with nucleotide identity $99.3 \%$. Intermediate strains Winterfield-2512 and Lukert formed cluster III (94.5\% identity). 'Hot' vaccine strains MB and $\mathrm{MB} / 3$ formed cluster IV with $99.5 \%$ nucleotide identity. Cluster V was represented by strains MB/5 and V877 (98.9\% identity) (Fig. 1).

To analyze phylogenetic relationship of vaccine and field strains we added previously described very virulent (Ukraine 1517, Ukrai-

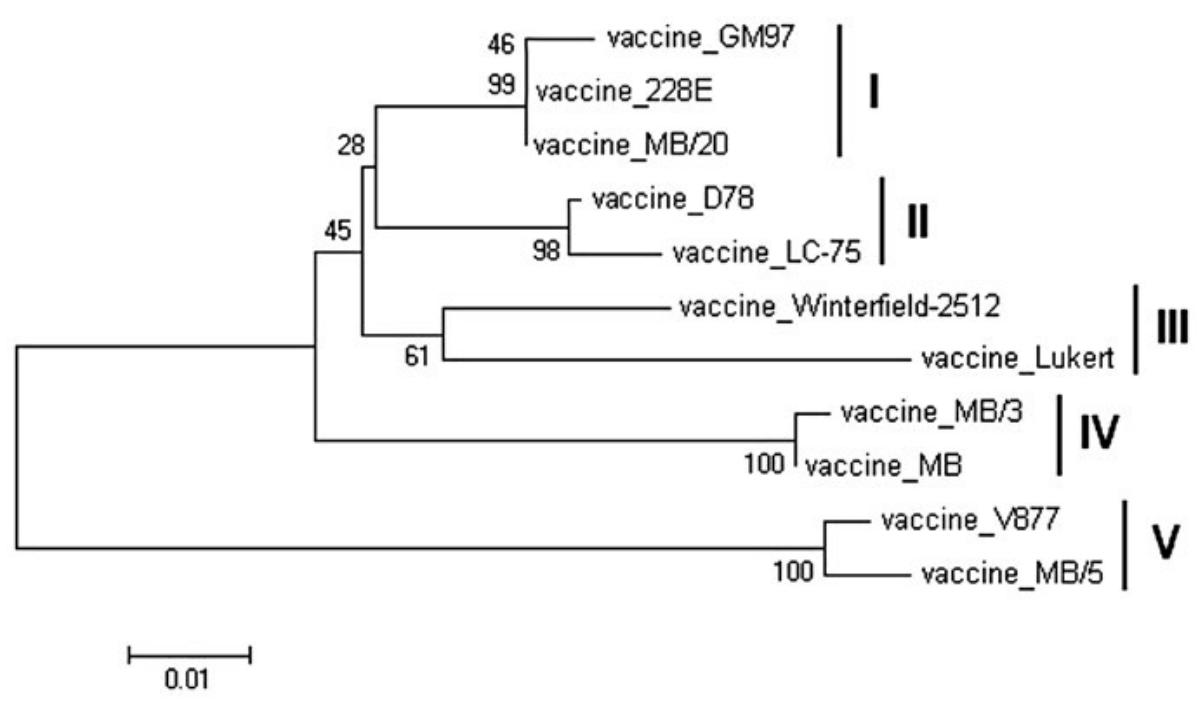

Fig.1. Phylogenetic tree of VP2 hypervariable region (HRV) nucleotide sequences of 11 vaccine strains commonly used in Ukraine. The Neighbor-Joining consensus tree is shown. Results of the bootstrap test (1000 replicates) are shown next to the branches [11]. The bar represents 0.01 nucleotide substitutions per site. Vaccine strains grouped phylogenetically into mild (II), intermediate (I, III, V) and "hot" (IV) strains. 
ne 55, Ukraine 691_35_4, Ukraine 691_35_5, Ukraine 760_45_4, Ukraine 2065, Ukraine 934, Ukraine 964) and classical virulent (Ukraine 1853, Ukraine 38 1943, Ukraine 43_1943, Ukraine 2045, Ukraine 58, Ukraine 691_24, Ukraine 760_45_5, Ukraine 1147) strains isolated from different regions of Ukraine to phylogenetic tree. It was shown that after addition of 16 Ukrainian field strains the basic structure of consensus tree remained the same and contained the same 5 clusters (Fig. 2). 8 very virulent field isolates clustered together with 'hot' and 8 classical virulent - with intermediate vaccine strains. There also were no field strains represented in cluster III (Fig. 2).

To determine antigenic difference among vaccine and field strains, the deduced amino acid substitutions in the variable VP2 (vVP2)

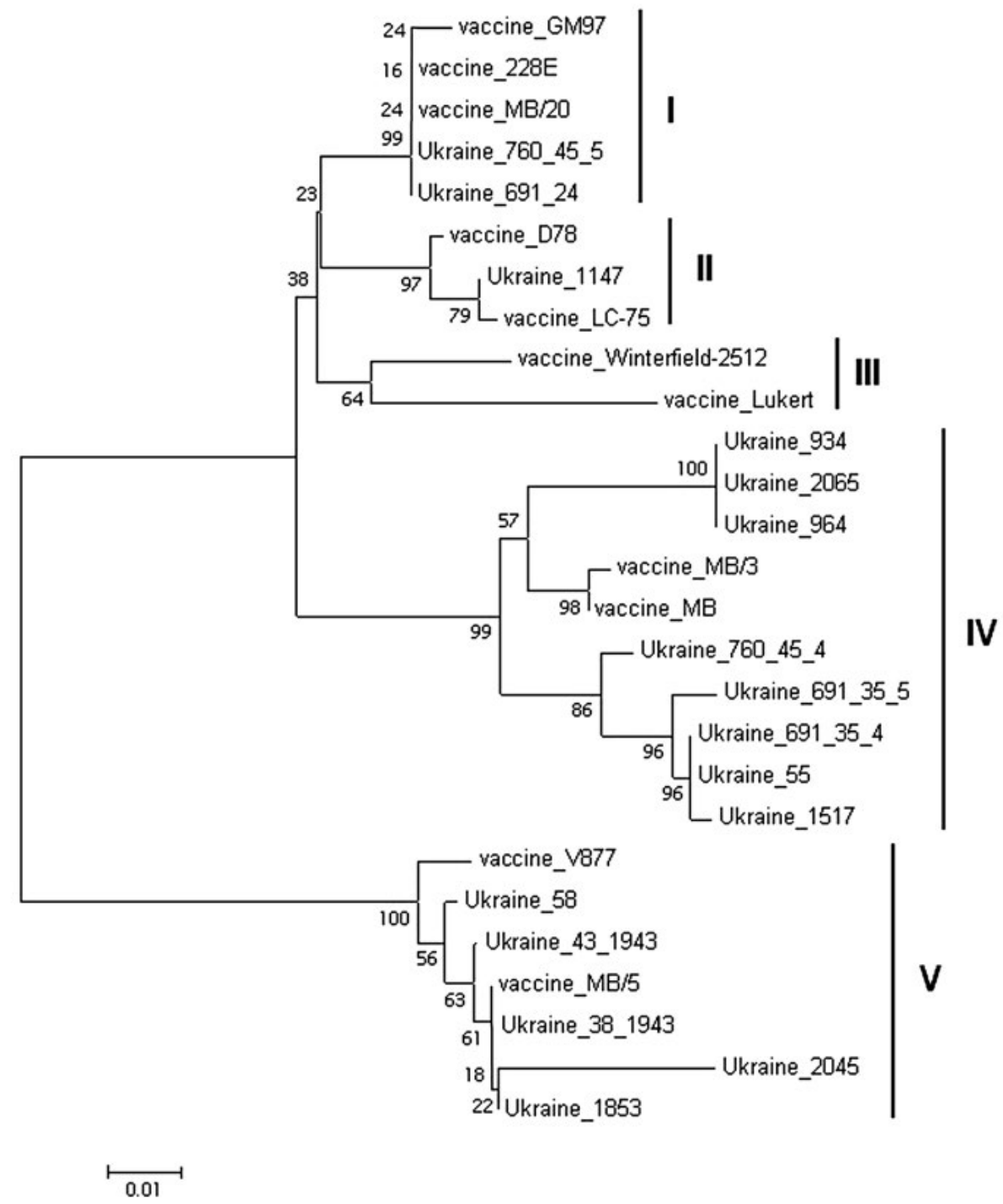

Fig. 2. Phylogenetic tree of hypervariable region (HRV) nucleotide sequences of 11 vaccine strains and 16 field IBDV isolates from Ukraine. The Neighbor-Joining consensus tree is shown. Results of the bootstrap test (1000 replicates) are shown next to the branches [11]. The bar represents $0.01 \mathrm{nu}-$ cleotide substitutions per site. IBDV strains formed 5 clusters. Classical virulent IBDV strains are represented in clusters I, II and V. Very virulent IBDV strains are represented in cluster $\mathrm{V}$. Cluster III contains only intermediate vaccine strains. 


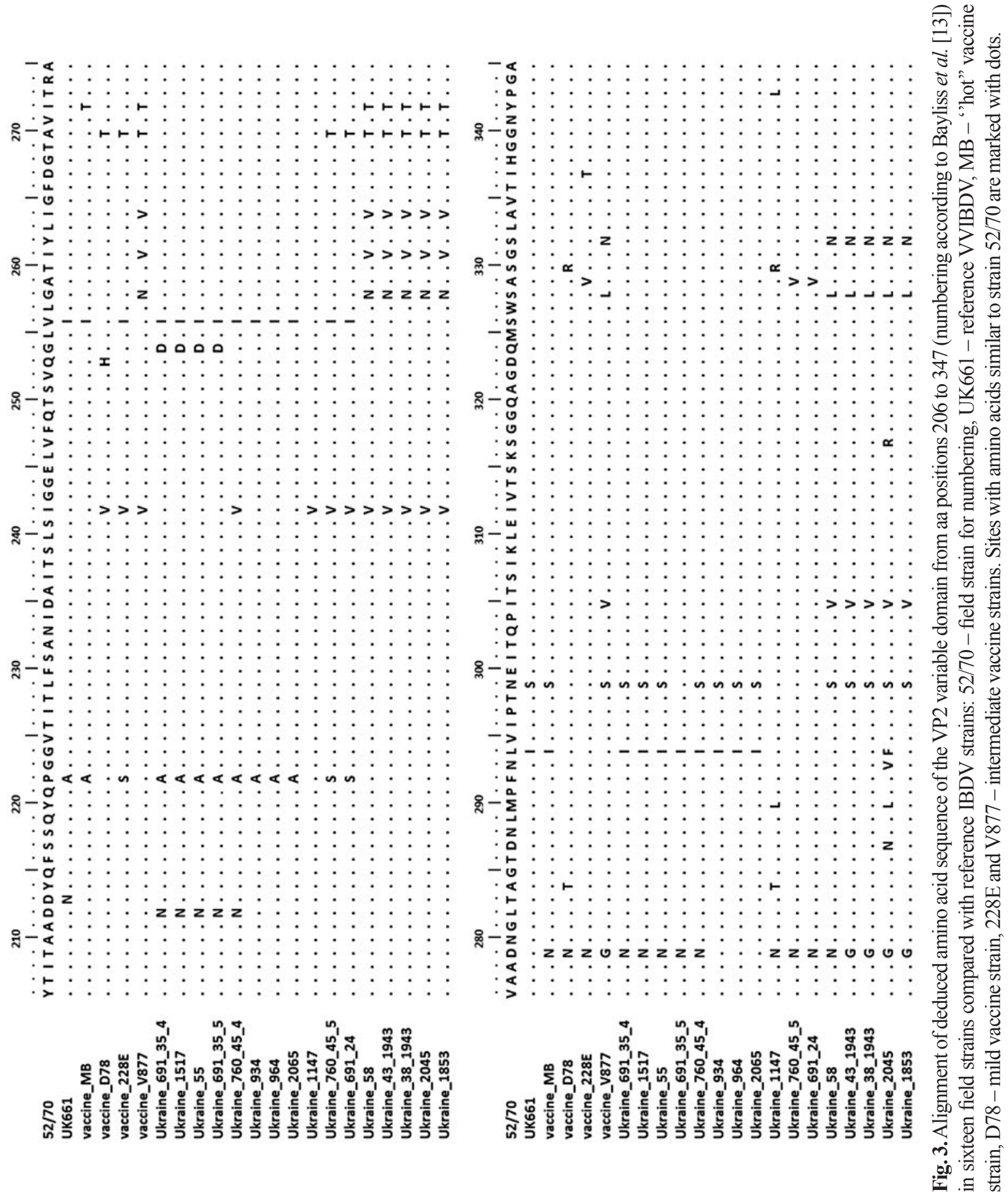


region (206-350 aa) [12] were analyzed (Fig. 3). For the reference and numbering the strain 52/70 (GeneBank accession no. D00869) was chosen [13]. The reference vvIBDV strain UK661 (GeneBank accession no. AJ878898) and 'hot' vaccine strain MB (GeneBank accession no. AY739669) were taken for comparison with Ukrainian vvIBDV isolates. The analyzed region included 142 amino acid residues, from position 206 to 347. It was found that none of the local examined isolates was of vaccine or attenuated origin due to absence of 253-Histidine and 284-Threonine mutations that are typically found in attenuated vaccine strains $[14$, 15]. Figure 3 demonstrated that 8 of the examined strains (Ukraine 1517, Ukraine 55, Ukraine 691_35_4, Ukraine 691_35_5, Ukraine 760 45_4, Ukraine 2065, Ukraine 934, Ukraine 964) showed the characteristic of vvIBDV amino acid substitutions at residues 222A, 242I (except Ukraine 760_45_4), 256I, 294I, and 299S (except Ukraine 691_35_5). 8 strains had the serine-rich heptapeptide SWSASGS which was found next to the second hydrophilic region 326-332 that confirmed the highly virulence nature among the analyzed strains [14]. In five strains [Ukraine 1517, Ukraine 55, Ukraine 691_35_4, Ukraine 691_35_5, Ukraine 760_45_4] D to $\mathrm{N}$ mutation in 212 aa position was found, which was not described before. The influence of this mutation on IBDV virulence should be analyzed in further studies.

The comparison amino acid sequences of very virulent isolates and vaccine strain $\mathrm{MB}$ showed that in the discussed critical aa sites MB strain is similar to the analyzed field isolates. These results indicate that based on phylogenetic and the amino acid sequence analyses vaccine strains can be chosen for preven- tion IBD in farms. The most phylogenetically and antigenically close to vvIBDV isolates were $\mathrm{MB}$ and $\mathrm{MB} / 3$ strains.

\section{Conclusion}

As a result of phylogenetic analysis the vaccine strains studied in the research formed 5 genetic clusters. After addition of the field strains for analysing they clustered to the most similar vaccine strains. Deduced amino acid analysis revealed that 8 Ukrainian isolates had the amino acid sites common for very virulent strains. These strains were antigenically close to the 'hot' vaccine strains. Therefore, these data can be used for the vaccine selection for prevention IBD in each particular poultry farm.

\section{REFERENCES}

1. Berg TP. Acute infectious bursal disease in poultry: a review. Avian Pathol. 2000;29(3):175-94.

2. Alkie TN, Rautenschlein S. Infectious bursal disease virus in poultry: current status and future prospects. Veteri-nary Medicine: Research and Reports. 2016; 2016(7):9-18.

3. Jackwood DJ, Sreedevi B, LeFever LJ, SommerWagner SE. Studies on naturally occurring infectious bursal disease viruses suggest that a single amino acid substitution at position 253 in VP2 increases pathogenicity. Virology. 2008;377(1):110-6.

4. Camilotti E, Moraes LB, Furian TQ, Borges KA, Moraes HLS, Salle CTP. Infectious Bursal Disease: Pathogenicity and Immunogenicity of Vaccines. Rev Bras Cienc Avic. 2016; 18(2):303-8.

5. Jackwood DJ. Advances in vaccine research against economically important viral diseases of food animals: Infectious bursal disease virus. Vet Microbiol. 2017;206:121-125.

6. Boudaoud A, Mamache B, Tombari W, Ghram A. Virus mutations and their impact on vaccination against infectious bursal disease (Gumboro disease). Rev Sci Tech. 2016;35(3):875-897. 
7. Pastyria A, Sobko I, Polischuk V. Genetic characterization of infectious bursal disease virus isolates in Ukraine. Bulletin of Taras Shevchenko National University of Kyiv. Series: Biology. 2016; 72(2):24-27.

8. Kataria RS, Tiwari AK, Bandyopadhyay SK, Kataria $J M$, Butchaiah $G$. Detection of infectious bursal disease virus of poultry in clinical samples by RTPCR. Biochem Mol Biol Int. 1998;45(2):315-22.

9. Tamura K, Stecher G, Peterson D, Filipski A, Kumar S. MEGA6: Molecular Evolutionary Genetics Analysis version 6.0. Mol Biol Evol. 2013;30(12):2725-9.

10. Saitou N, Nei M. The neighbor-joining method: a new method for reconstructing phylogenetic trees. Mol Biol Evol. 1987;4(4):406-25.

11. Felsenstein J. Confidence limits on phylogenies: an approach using the bootstrap. Evolution. 1985;39(4): 783-791.

12. Mawgod SA, Arafa AS, Hussein HA. Molecular genotyping of the infectious bursal disease virus (IBDV) isolated from Broiler Flocks in Egypt. Int J Vet Sci Med. 2014; 2(1):46-52

13. Bayliss CD, Spies U, Shaw K, Peters $R W$, Papageorgiou A, Müller H, Boursnell ME. A comparison of the sequences of segment $\mathrm{A}$ of four infectious bursal disease virus strains and identification of a variable region in VP2. J Gen Virol. 1990;71 (Pt 6):1303-12.

14. Mohamed MA, Elzanaty KES, Bakhit BM, Safwat $M M$. Genetic Characterization of Infectious Bursal Disease Viruses Associated with Gumboro Outbreaks in Commercial Broilers from Asyut Province, Egypt. ISRN Vet Sci. 2014; 2014(1):916412.

15. Jackwood DJ, Sommer-Wagner SE. Amino acids contributing to antigenic drift in the infectious bursal disease Birnavirus (IBDV). Virology. 2011;409(1):33-7.

\section{Характеристика вакцинних та польових штамів вірусу ІБХ в Україні з метою правильного підбору вакцин для профілактики захворювання}

А. С. Пастиря, І. Г. Будзанівська, В. П. Поліщук

Вірус інфекційної бурсальної хвороби (IБХ) викликає висококонтагіозне захворювання курчат та поширений у всьому світі. Головним антигеном є білок VP2. Ген $V P 2$ містить гіперваріабельний регіон, мутації в якому призводять до появи нових антигенних варіантів вірусу ІБХ. Для попередження інфікування використовують вакцинацію, ефективність якої залежить від генетичної спорідненості вакцинних та польових штамів вірусу. Мета. проаналізувати нуклеотидну послідовність різних вакцинних та польових штамів вірусу ІБХ, поширених в господарствах України. Методи. У дослідженні було використано 11 вакцинних та 16 польових штамів вірусу ІБХ. РНК виділяли методом магнітної сорбції, здійснювали реакцію зворотної транскрипції та постановку ПЛР із специфічними праймерами до гену VP2. Амплікони секвенували, нуклеотидну та амінокислотну послідовність аналізували за допомогою програми $M E G A$ 6. Результати. 11 вакцинних штамів формували 5 кластерів. Кластер I містив штами GM97, 228E та $M B / 20$. Кластер II бус сформований м'якими штамами LC-75 та D78. Середні штами Winterfield-2512 та Lukert формували кластер III. «Гарячі» штами $M B$ та $M B / 3$ містились у кластері IV. Кластер V містив штами $M B / 5$ та V877. Після включення 16 польових ізолятів, виявлених в Україні, структура дерева не змінилась. Вісім 3 них групувалися разом 3 «гарячими», 5 - 3 середніми та 3 - 3 м'якими вакцинними штамами. Порівняння амінокислотних послідовностей підтвердило антигенну спорідненість штамів, що знаходились в одному кластері. Висновки. Отримані результати можуть бути використані для підбору вакцин для профілактики ІБХ в кожному окремому господарстві України.

К л юч о в і с л о в а: вірус ІБХ, польові штами, вакцинні штами, високовірулентні штами, філогенетичний аналіз.

\section{Характеристика вакцинных и полевых штаммов вируса ИББ в Украине с целью правильного подбора вакцин для профилактики болезни}

А. С. Пастыря, И. Г. Будзанивская, В. П. Полищук Вирус инфекционной бурсальной болезни (ИББ) вызывает высококонтагиозное заболевание цыплят и распространен во всем мире. Главным антигеном вируса является белок VP2. Ген VP2 содержит гипервариабельный регион, мутации в котором приводят к появлению новых антигенных вариантов вируса ИББ. Для предупреждения инфицирования используют вак- 
цинацию, эффективность которой зависит от генетического родства вакцинных и полевых штаммов вируса. Цель. проанализировать нуклеотидную последовательность различных вакцинных и полевых штаммов вируса ИББ, распространенных в хозяйствах Украины. Методы. В исследовании были использованы 11 вакцинных и 16 полевых штаммов вируса ИББ. РНК выделяли методом магнитной сорбции, осуществляли реакцию обратной транскрипции и постановку ПЦР со специфическими праймерами к гену VP2. Ампликоны секвенировали, нуклеотидную и аминокислотную последовательность анализировали с помощью программы MEGA 6. Результаты. 11 вакцинных штаммов формировали 5 кластеров. Кластер I содержал штаммы $G M 97,228 E$ и $M B / 20$. Кластер II был сформирован мягкими штаммами $L C-75$ и $D 78$. Средние штаммы Winterfield-2512 и Lukert формировали кластер
III. «Горячие» штаммы $M B$ и $M B / 3$ содержались в кластере IV. Кластер V содержал штаммы $M B / 5$ и V877. После включения 16 полевых изолятов, выявленных в Украине, структура дерева не изменилась. Восемь из них группировались вместе с «горячими», 5 - средними и 3 - мягкими вакцинными штаммами. Сравнение аминокислотных последовательностей подтвердило антигенное родство штаммов, находящихся в одном кластере. Выводы. Полученные результаты могут быть использованы для подбора вакцин для профилактики ИБХ в каждом отдельном хозяйстве Украины.

К л юч е в ы е с л о в а: вирус ИБХ, полевые штаммы, вакцинные штаммы высоковирулентные штаммы, филогенетический анализ. 